\title{
Selected blood parameters altered by different doses of pesticide Malathion in albino rat (Rattus-norvegicus)
}

\author{
Sharma C. D. ${ }^{1}$, Shukla Neha ${ }^{2}$, Bansal Geeta ${ }^{3}$ \\ Received: 07.07.2020 \\ Revised: 28.08.2020 \\ Accepted: 23.10 .2020
}

\begin{abstract}
Organophosphate pesticides Malathion used as pest control agent in agriculture, household, kitchen and other places. Malathion is found in market with different trade names. It is used with its action properties against various insects and pest. It is used with the largest group of poisonous substances that are widely broadcast today. Present study is based on the effects of different doses of Malathion on routine hematological parameters like RBCs, WBCs, Hb\%, CT, PT, ESR, PCV, MCV, MCH, and MCHC. Four doses were selected according to the body weight of albino rats. The doses were selected as four types on the basis of per kilogram body weight of albino rat. They were $25,50,75,100 \mathrm{mg}$ per $\mathrm{Kg}$ body weight for 7 and 15 days of treatment.The findings indicate that the above parameter fluctuates significantly as amount of dose increases. Hematological parameter indicates that the total body of the animals gets affected by the Malathion. It causes various other toxicological effects on the body of albino rats. There was a combined study of male and female albino rats.
\end{abstract}

Key Words: Dose, Erythrocyte, ESR, Hemoglobin, Leucocytes, Malathion Pesticides

\section{Introduction}

Pesticides are the basic need of agriculture practice all over the world because it fulfills the aim of protection of plants from the harmful pests. Peoples are not aware about harmful action of pesticides on the human body. Workers used pesticides directly in his cropland without any precaution and prescription of experts. The use of pesticides in our country has been increasing considerably to boost the agricultural output. The beneficial effect also is obtained by pest killing effects on crops as reported by Hayes and Laws (1990). However, human beings, spray man, farmers and population in general are exposed to them and run the risk of pesticide toxicity. Cases of organophosphate toxicity caused by different pesticide have been reported in large numbers from different parts of the globe. According to WHO someone in the developing world is poisoned by pesticides every minute. Conservative estimates indicate that about fifty thousand and seven hundred people suffer from pesticide poisoning every year and about fourteen thousands of these

\footnotetext{
Author's Address

${ }^{1}$ Department of Zoology Krishna College of Science and

Technology. Bijnor U.P (India)

${ }^{2}$ NSIT Delhi University Delhi

${ }^{3}$ Department of Zoology D.N. (P.G) College Meerut.U.P

E-mail.: sharmachandra049@gmail.com
}

prove fatal. There are estimated Seventy thousand and three hundred cases of human poisoning by pesticides in developing countries every year with near about ten thousand deaths. The insecticidal property of Malathion was discovered in 1950 by American Cyanamid Company. Damalas and Koutroubas (2016) also noticed such type of problems in farmers. Since then it is extensively used as pesticides and insecticide. India's annual requirement is more than 10,000 metric tons. Such an extensive use of organophosphorus insecticide in our agriculture and public health practice may involve a good deal of risk. In order to take a realistic view of the hazardous consequent by use of pesticides by this group, the need for a critical study of nature in the extent of the likely outcome under the existing conditions in our country has become a matter of paramount importance. The study is therefore conducted to determine the Malathion induced hematological inconsistency on albino rats exposed to this pesticide.

\section{Material and Methods \\ Selection of Pesticide}

For present study Malathion pesticide was selected because of their maximum use in the agriculture field in Indian scenario. It is an organophosphorus 
insecticide. It is sold in the trade name Cythion or Malathion. It is brownish liquid. Malathion is common pesticide accepted in different forms by the local farmers. It is widely used for pest control in vegetable and field crops.

\section{Experimental Animal}

Sexually mature albino rats (Rattus-norvegicus) of controlled breed were procured from Humdard University Delhi and kept under controlled condition in Animal house of Zoology Department D.N. (PG) College Meerut U.P (India). Rats are selected for experiment as 60 to $200 \mathrm{gm}$. of their body weight. Before commencement of experiment the animals were acclimatized under laboratory conditions for a week according to the guideline of animal ethical society India. During acclimatization the normal water and food was given to animals. Then 40 rats for experiment are divided into five groups, 8 rats in each group, according to the dose of Malathion, were decided. After that animals group A was consider as control and remaining four groups were treated as experimental groups. Different doses of Malathion administered up to 7 and 15 days by the help of syringe. The dose of Malathion given to different experimental groups as Group A-Control (No dose administered)

Group $B-25 \mathrm{mg}$ per kg body weight per day. Group $C-50 \mathrm{mg}$ per kg body weight per day. Group $D-75 \mathrm{mg}$ per kg body weight per day. Group E-100 mg per kg body weight per day. For haematological study animal are slaughtered after 7 and 15 days of treatment. The blood of slaughtered rat was collected by direct hart punctured by syringe. The blood sample was collected into 2 sample tubes: one was with EDTA (1-2 IU/ml) and another was without EDTA.

\section{Parameters of Hematological studies:}

$>$ RBCs were counted by neumbour's haemometer using Hayem's solution.

$>$ Hemoglobin $(\mathrm{Hb} \%)$ was estimated following Sahli, (1962) method.

$>$ WBCs was counted by neumbour's haemometer using Turk's solution.

$>$ Packed Cell Volume (PCV) by Wintrobe's method (3000 rpm for 1 hour).

$>\mathrm{MCH}, \mathrm{MCV}, \mathrm{MCHC}$ by standard formula as

$M C H=\frac{H b \text { in gm.per } 100 \mathrm{ml} \text { of blood }}{R B C \sin \text { million } \mathrm{mm} 3} \times 10(\mathrm{Pg})$

$$
\begin{gathered}
M C V=\frac{P C V \text { per } 100 \mathrm{ml} \text { of blood }}{\text { RBCs in million } \mathrm{mm} 3} \times 10(\mathrm{Fl}) \\
M C H C=\frac{\text { Hbin gm per } 100 \mathrm{ml} \text { ofblood }}{P C V \text { per } 100 \mathrm{ml} \text { of blood }} \times 100(\mathrm{~g} / \mathrm{l}) \\
>\quad \text { Clotting Time (CT), Prothrombin Time } \\
\text { (PT) by Lee and White method. }
\end{gathered}
$$

Statistical study: Data is collected and calculated by Standard deviation to calculate the variation of parameter. For statistical significance we applied student $\mathrm{T}$ test. $\mathrm{T}$ test is defined as the quantity representing the difference between the sample mean and true mean expressed as

$$
t=\frac{\text { difference between sample mean }}{\text { standard error of the difference between mean }}
$$

Calculate the $\mathrm{t}$ value i.e., the ratio between the observed difference and its standard error by the formula.

\section{Results and Discussion \\ RBCs value and Haemoglobin (Hb \%)}

RBCs play a vital role to gaseous exchange in between lungs and cells of the body. Deficiency of Erythrocytes is diagnosed in the anemia condition. Result present in table 1 clearly indicates that the number of RBCs suddenly decline with the increasing dose of pesticide. It was observed that dose of $25 \mathrm{mg}$ per $\mathrm{kg}$ body weight per day of Malathion, the RBCs (erythrocytes) decreased gradually with $3.31 \%$ at 7 days and $4.31 \%$ after 15 days as shown in (Fig.1) in comparison with the control group. Above results are found in agreement with the previous findings of Naik et al. (2018) who on their study observed that the chlorpyrifos cause reduction in RBCs, $\mathrm{Hb}, \mathrm{PCV}$ whereas WBC count shows increased level in single, double and multiple doses respectively. Bhai et al. (1971) also found the similar results. But with a dose of $50 \mathrm{mg}, 75 \mathrm{mg}, 100$ mg per $\mathrm{kg}$ body weight per day number of RBCs decreased gradually after 7 days by $28.70 \%$ and after 15 days of treatment the RBCs decreases by $38.7 \%$ in comparison with the control group. Our findings were found similar to the findings of Rahman et al. (1990) who concluded that after treatment of Chlorpyriphos, anemic condition was reported due to decrease in RBCs and hemoglobin amount. 
Table 1. Selected parameter of blood of albino rats fluctuate with different dose of Malathion

\begin{tabular}{|c|c|c|c|c|c|c|c|c|c|c|c|}
\hline & & $\mathrm{Hb}$ gm/dl & $\begin{array}{l}\text { RBCs } \\
\text { Mill/ } / \mathbf{m m}^{3}\end{array}$ & $\begin{array}{l}\text { WBCs } \\
10^{3} / \mathrm{mm}^{3}\end{array}$ & PCV\% & $\begin{array}{l}\text { ESR } \\
\mathrm{mm} / \mathrm{hr}\end{array}$ & PT sec. & $\begin{array}{l}\text { CT } \\
\text { minute }\end{array}$ & $\begin{array}{l}\text { MCH } \\
\text { pg }\end{array}$ & $\begin{array}{l}\text { MCV } \\
\text { fL }\end{array}$ & $\begin{array}{l}\text { MCHC } \\
\text { g/dl }\end{array}$ \\
\hline Control & $\begin{array}{l}\text { mean } \\
\pm \mathrm{SD}\end{array}$ & $\begin{array}{l}14.8 \\
\pm 0.08\end{array}$ & $\begin{array}{l}17.8 \\
\pm 0.62\end{array}$ & $\begin{array}{l}8.9 \\
\pm 0.6 \underline{8}\end{array}$ & $\begin{array}{r}46.10 \\
\pm 2.5\end{array}$ & $\begin{array}{l}11.00 \\
\pm 1.06\end{array}$ & $\begin{array}{l}22.5 \\
\pm 2.67\end{array}$ & $\begin{array}{l}2.62 \\
\pm 0.91\end{array}$ & $\begin{array}{l}7.52 \\
\pm 0.78\end{array}$ & $\begin{array}{l}25.85 \\
\pm 2.67\end{array}$ & $\begin{array}{l}29.37 \\
+4.12\end{array}$ \\
\hline \multirow[t]{2}{*}{$\begin{array}{l}\text { Dose } 25 \\
\text { mg/kg.b.wt/day }\end{array}$} & $\begin{array}{l}\mathrm{d} \\
\mathrm{mg}\end{array}$ & $12 \pm 1.51$ & $\begin{array}{l}17.21 \pm \\
1.74\end{array}$ & $\begin{array}{l}9.5 \\
\pm 1.41\end{array}$ & $\begin{array}{l}43.5 \\
+3.85\end{array}$ & $\begin{array}{l}12.00 \\
\pm 1.51\end{array}$ & $\begin{array}{r}25.00 \\
+0.75\end{array}$ & $\begin{array}{l}3.12 \\
\pm 0.64\end{array}$ & $\begin{array}{l}7.00 \\
\pm 0.95\end{array}$ & $\begin{array}{r}25.59 \\
+4.12\end{array}$ & $\begin{array}{r}27.72 \\
+3.85\end{array}$ \\
\hline & $15 \mathrm{~d}$ & $\begin{array}{r}11.37 \\
\pm 1.18\end{array}$ & $\begin{array}{l}17.03 \\
\pm 1.44\end{array}$ & $\begin{array}{l}9.9 \\
\pm 1.68\end{array}$ & $\begin{array}{r}46.12 \\
+3.87\end{array}$ & $\begin{array}{l}11.75 \\
\pm 1.66\end{array}$ & $\begin{array}{r}24.37 \\
\pm 0.51\end{array}$ & $\begin{array}{l}3.75 \\
\pm 1.16\end{array}$ & $\begin{array}{l}6.73 \\
\pm 1.03\end{array}$ & $\begin{array}{r}27.29 \\
\pm 3.60\end{array}$ & $\begin{array}{r}24.83 \\
+3.56\end{array}$ \\
\hline \multirow[t]{2}{*}{$\begin{array}{l}\text { Dose } 50 \mathrm{mg} \\
\mathrm{mg} / \mathrm{kg} . b . w t / \text { day }\end{array}$} & $7 \mathrm{~d}$ & $\begin{array}{r}10.12 \\
+1.55\end{array}$ & $\begin{array}{r}16.59 \\
\pm 1.10\end{array}$ & $\begin{array}{l}9.9 \\
\pm 1.68\end{array}$ & $\begin{array}{l}42.75 \\
+1.90\end{array}$ & $\begin{array}{r}12.25 \\
\pm 1.66\end{array}$ & $25 \pm 0.75$ & $\begin{array}{l}3.12 \\
\pm 1.24\end{array}$ & $\begin{array}{l}6.10 \\
+0.92\end{array}$ & $\begin{array}{r}25.87 \\
+2.23\end{array}$ & $\begin{array}{r}23.76 \\
+4.22\end{array}$ \\
\hline & $15 \mathrm{~d}$ & $\begin{array}{l}9.87 \pm \\
1.72\end{array}$ & $\begin{array}{l}15.77 \\
\pm 1.22\end{array}$ & $\begin{array}{l}10.5^{* *} \\
\pm 1.03\end{array}$ & $\begin{array}{l}41.75 \\
\pm 2.25\end{array}$ & $\begin{array}{r}13.87 \\
\pm 1.35\end{array}$ & $\begin{array}{r}25.87 \\
\pm 1.88\end{array}$ & $3.5 \pm 1.30$ & $\begin{array}{l}6.31 \\
\pm 1.37\end{array}$ & $\begin{array}{r}26.65 \\
\pm 2.99\end{array}$ & $\begin{array}{r}23.56 \\
+3.45\end{array}$ \\
\hline \multirow[t]{2}{*}{$\begin{array}{l}\text { Dose } 75 \mathrm{mg} \\
\mathrm{mg} / \mathrm{kg} . b . w t / \text { day }\end{array}$} & $7 \mathrm{~d}$ & $\begin{array}{l}9.5 \\
\pm 1.41\end{array}$ & $\begin{array}{r}15.42 \\
\pm 0.98\end{array}$ & $\begin{array}{l}10.6 \\
+1.05\end{array}$ & $\begin{array}{l}39.5 \\
\pm 1.77\end{array}$ & $\begin{array}{r}15.12 \\
\pm 1.35\end{array}$ & $\begin{array}{l}27.25 \\
\pm 1.90\end{array}$ & $\begin{array}{l}4.5^{* * *} \\
\pm 0.72\end{array}$ & $\begin{array}{l}6.14 \\
\pm 0.76\end{array}$ & $\begin{array}{r}25.74 \\
\pm 2.72\end{array}$ & $\begin{array}{l}24.11 \\
+4.11\end{array}$ \\
\hline & $15 \mathrm{~d}$ & $\begin{array}{l}9.5^{* *} \\
\pm 1.77\end{array}$ & $\begin{array}{l}14.93^{* *} \\
\pm 1.14\end{array}$ & $\begin{array}{l}12.5^{* *} \\
\pm 1.21\end{array}$ & $\begin{array}{l}36.25^{*} \\
\pm 2.25\end{array}$ & $\begin{array}{l}16.87^{* *} \\
\pm 1.24\end{array}$ & $\begin{array}{r}27.15 \\
\pm 3.01\end{array}$ & $\begin{array}{l}5.37^{* * *} \\
\pm 0.51\end{array}$ & $\begin{array}{l}6.35 \\
\pm 1.02\end{array}$ & $\begin{array}{l}24.40 \\
\pm 2.29\end{array}$ & $\begin{array}{l}26.14^{* * *} \\
\pm 4.32\end{array}$ \\
\hline \multirow[t]{2}{*}{$\begin{array}{l}\text { Dose } 100 \mathrm{mg} \\
\mathrm{mg} / \mathrm{kg} . b . w t / \text { day }\end{array}$} & $7 \mathrm{~d}$ & $\begin{array}{l}8.1 * * * \\
\pm .51\end{array}$ & $\begin{array}{l}12.69^{* *} \\
\pm 1.47\end{array}$ & $\begin{array}{l}14.4^{* * *} \\
\pm 1.03\end{array}$ & $\begin{array}{l}31.5^{* *} \\
\pm 1.77\end{array}$ & $\begin{array}{l}18.25^{* * *} \\
\pm 1.66\end{array}$ & $\begin{array}{r}32.25 \\
\pm 1.18\end{array}$ & $\begin{array}{l}5.75^{* * *} \\
\pm 0.46\end{array}$ & $\begin{array}{l}6.39 \\
\pm 1.47\end{array}$ & $\begin{array}{r}25.08 \\
\pm 2.89\end{array}$ & $\begin{array}{l}25.29 * * * \\
\pm 3.98\end{array}$ \\
\hline & $15 \mathrm{~d}$ & $\begin{array}{l}7.75^{* * *} \\
\pm 1.66\end{array}$ & $\begin{array}{l}10.90^{* * *} \\
\pm 1.33\end{array}$ & $\begin{array}{l}16.9^{* * *} \\
\pm 1.25\end{array}$ & $\begin{array}{l}30 * * * \\
\pm 2.82\end{array}$ & $\begin{array}{l}21.25^{* * *} \\
\pm 3.19\end{array}$ & $\begin{array}{r}36.12 \\
\pm 3.60\end{array}$ & $\begin{array}{l}11 * * * \\
\pm 1.06\end{array}$ & $\begin{array}{l}7.22 \\
\pm 1.06\end{array}$ & $\begin{array}{l}27.61 \\
\pm 1.84\end{array}$ & $\begin{array}{l}26.15^{* * *} \\
\pm 6.52\end{array}$ \\
\hline
\end{tabular}




\section{Sharma et al.}

Similar findings were reported by Kumar (1990) Taylor et al. (1968) who also reported the reduction in RBCs and $\mathrm{Hb} \%$. Prabhavati and Tombi (1988) also reported inhibition of $\mathrm{RBCs}$ and $\mathrm{Hb} \%$ due to toxicity of pesticides.

\section{Hb Value}

$\mathrm{Hb}$ findings of the study are represented in table 1. Study shows that haemoglobin concentration was found directly correlated to the RBCs count. Findings of the experiment indicates that when rats were treated with dose of $25 \mathrm{mg}$ per $\mathrm{kg}$ body weight per day the haemoglobin decreases insignificantly after 7 days of treatment as shown in fig. 2. The decrease was observed as $18.91 \%$ and after 15 days of treatment the $\mathrm{Hb} \%$ decreased significantly by $23.17 \%$, but with $50 \mathrm{mg}$ and $75 \mathrm{mg}$ per $\mathrm{kg}$ body weights of animal the value of $\mathrm{Hb} \%$ decrease randomly after 7 days by $31.62 \%$ and after 15 days it was decreased by $33.31 \%$. After treatment with dose of $100 \mathrm{mg}$ per $\mathrm{kg}$ body weight of animal, the value of haemoglobin was drastically reduced by $45.9 \%$ and after 15 days it was reduced by $47.62 \%$ as compared with control group. Similar findings were observed by Kartheek and David (2017), according to them an insecticide Phenylpyrazole causes significant changes of haematological parameter like $\mathrm{RBCs} \mathrm{Hb} \%$ etc. Similar findings were also given by Zartizian et al. (1961) as per their study infected Malathion 1/P in rats @ 500 $\mathrm{mg} / \mathrm{kg}$ there was 70,53 and $61 \%$ inhibition of brain RBCs and plasma ChE respectively after two hours. Sharma and Saxena (1983) analyses that haemorrhage conditions are found and decrease in $\mathrm{RBCs}$ and $\mathrm{Hb} \%$, they reported that the size of cell also reduces. Previously Jung- Hoon et al. (2005) reported the decline number of RBCs and haemolysis and due to either an increase in the rate at which haemoglobin concentration may be destroyed or a decrease in the haemoglobin synthesis. Conflicting findings with our result was found by Yekeen et al. (2007). They analyse in mice that pyrithroid deltamethrin effects on RBCs and other parameters were not noticible. Akinrotimi et al. (2009) and Ambali et al. (2010) on Tilapia guineensis, Solanke and Singh (2000) observe the similar effects of thiodon in rats and find similar result.

\section{PCV and WBCs}

The value of mean packed cell volume are represented in table 1 . Results of the findings of
PCV when compared with control group were found insignificant decrease at dose of $25 \mathrm{mg}$ per $\mathrm{kg}$ body weight per day after 7 days decrease of $5.6 \%$ and after 15 days of treatment decrease of $0.04 \%$ was observed but with a dose of $50 \mathrm{mg}$ per $\mathrm{kg}$ body weight per day $7.2 \%$ decrease was observed after 7 days while after 15 days of treatment the PCV decreased to $9.4 \%$. Our findings were in agreement with that of Madhavee (2006), who reported that the number of erythrocyte decreases due to ribosomal abnormalities in mice, which clearly indicates that the toxic agents directly affect the genetic material of the cell. The PCV decreased gradually after 7 days which was observed as $31.67 \%$ while after 15 days it was noted as $34.92 \%$ decrease as shown in Fig (3) and Table 1. Our findings countered to the previous observation of Prasad and Rai (1988) who reported increase in PCV in rats treated with $10 \%$ BHC. During the present study in the rats the PVC value decreases significantly in comparison with low dose to high dose of pesticide but increase in same pesticide dose in between 7 to 15 days in rats. WBCs values observed during experimental studies are presented in table 1 which indicates gradual increase as compared to control group this may be due to body response of animals against toxic exogenous substance i.e. Malathion. A gradual increase in the value of leukocyte (WBCs) was found due to the toxic effect of Malathion as represented in fig. 2. Table1 indicates that the number of WBCs increases slightly at lower dose of $25 \mathrm{mg}$ per kg body weight per day but at the dose of 50mg per kg body weight per day the number of WBCs increases simultaneously. Graphical value indicates that during treatment with $75 \mathrm{mg}$ per kg body weight per day and $100 \mathrm{mg}$ per $\mathrm{kg}$ body weight per day dose the numbers are significantly increased. Our findings are in agreement withthat of Singh et al., (2016) who reported that the number of WBCs increase and decrease depends on the surroundings. Same observations were noticed by Das and Mukherjee (2003) who reported the number of WBCs increase due to stimulation of lymphopoisis. Other works find the similar incensement of WBCs in experimental animal as effects of aldrin by Kumar et al. (1996). Choudhary and Joshi (2002) reported the effect of endosulfan pesticide. Rahman and Siddiqui, (2006) reported the effects of cypermethrin pesticide. Siddiqui, (2004) found that after exposure of imidacloprid and quinalphos did not effects the PCV and $\mathrm{Hb}$ level in White leghorn cockerels. 


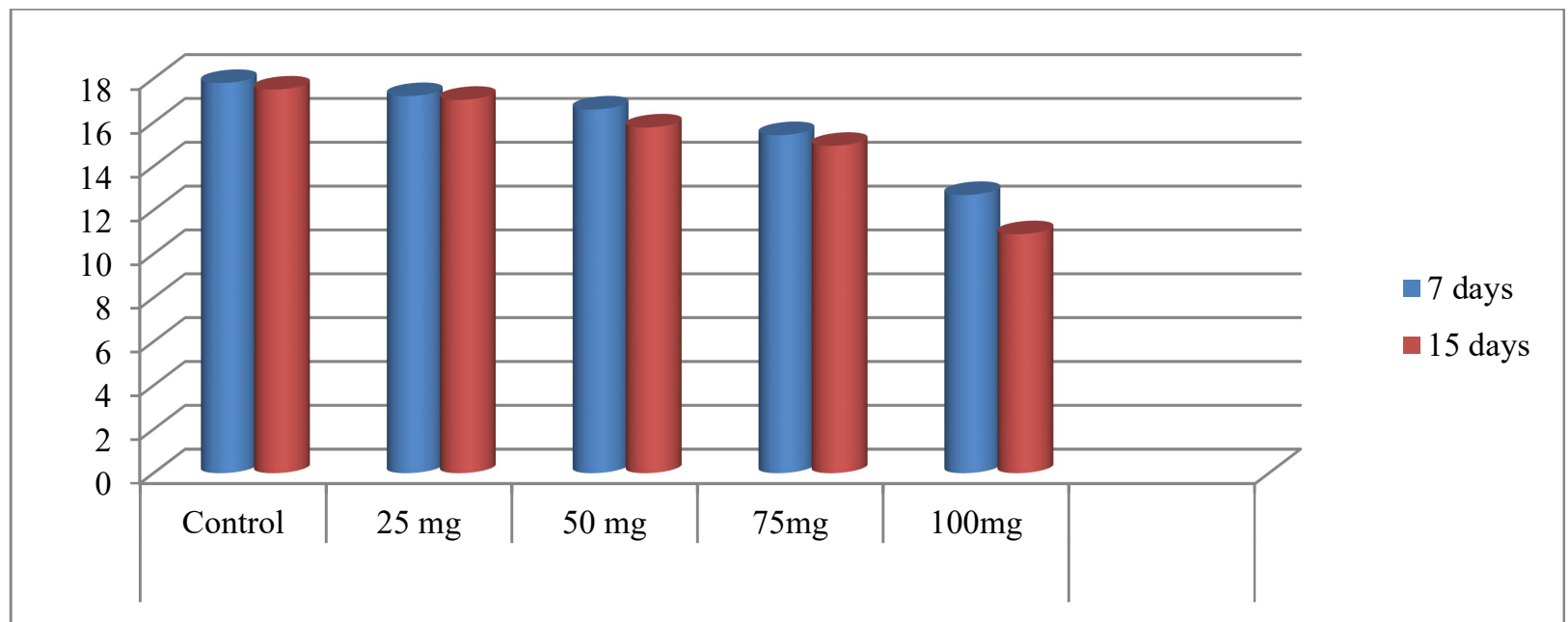

Fig 1. Effect of different dose of Malathion on RBCs million/ $/ \mathrm{mm}^{3}$

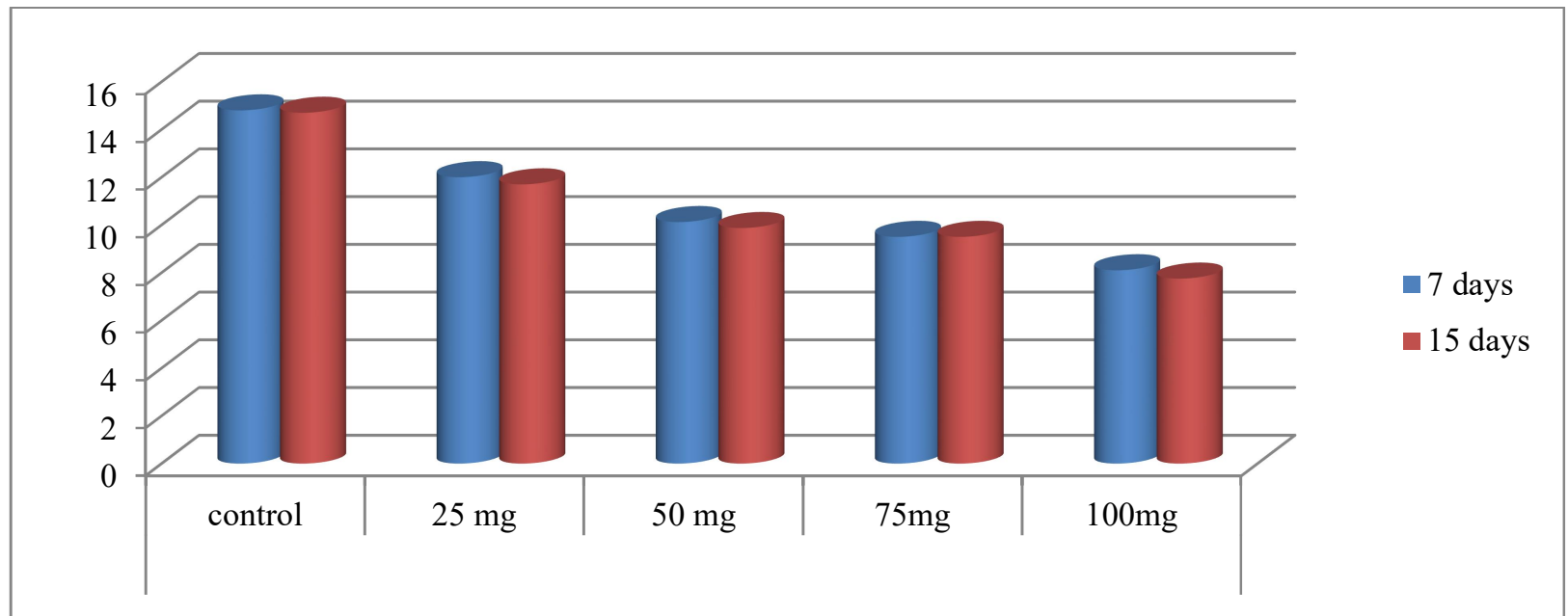

Fig 2. Effect of different dose of Malathion on $\mathrm{Hb} \mathrm{gm} / \mathrm{dl}$

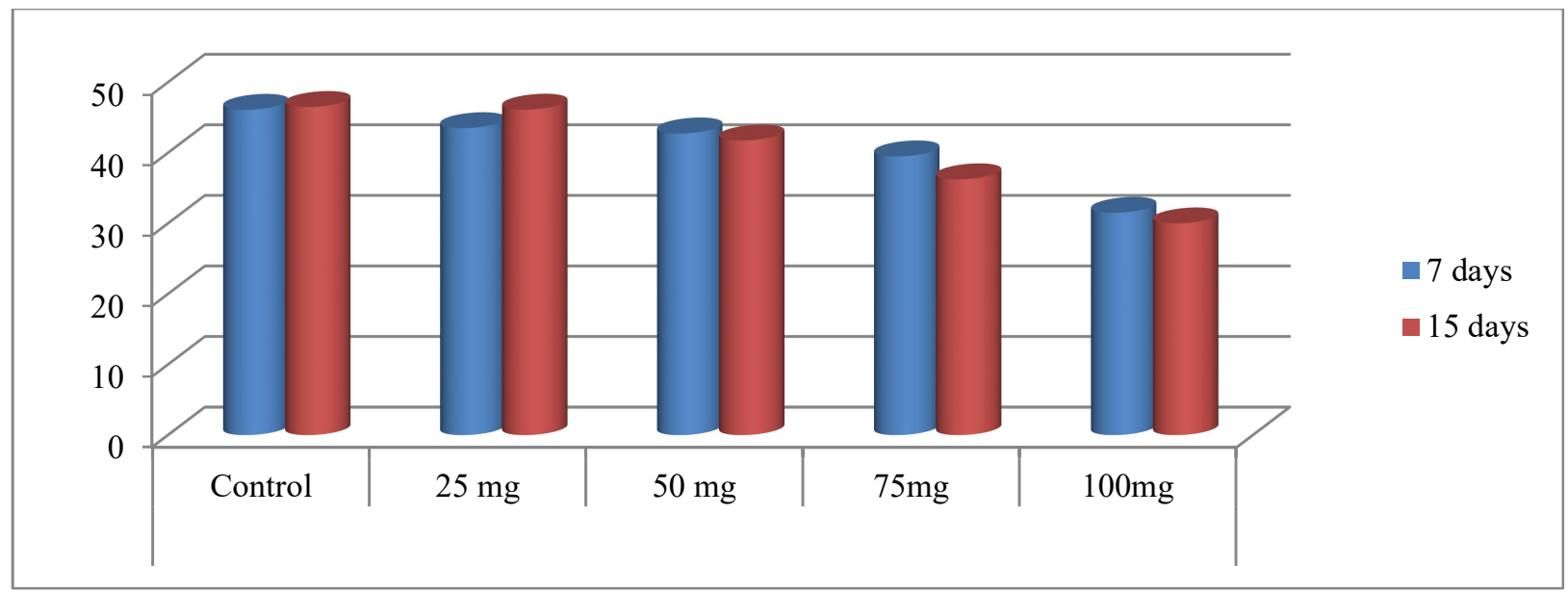

Fig 3. Effect of different dose of Malathion on PCV \% 
Sharma et al.

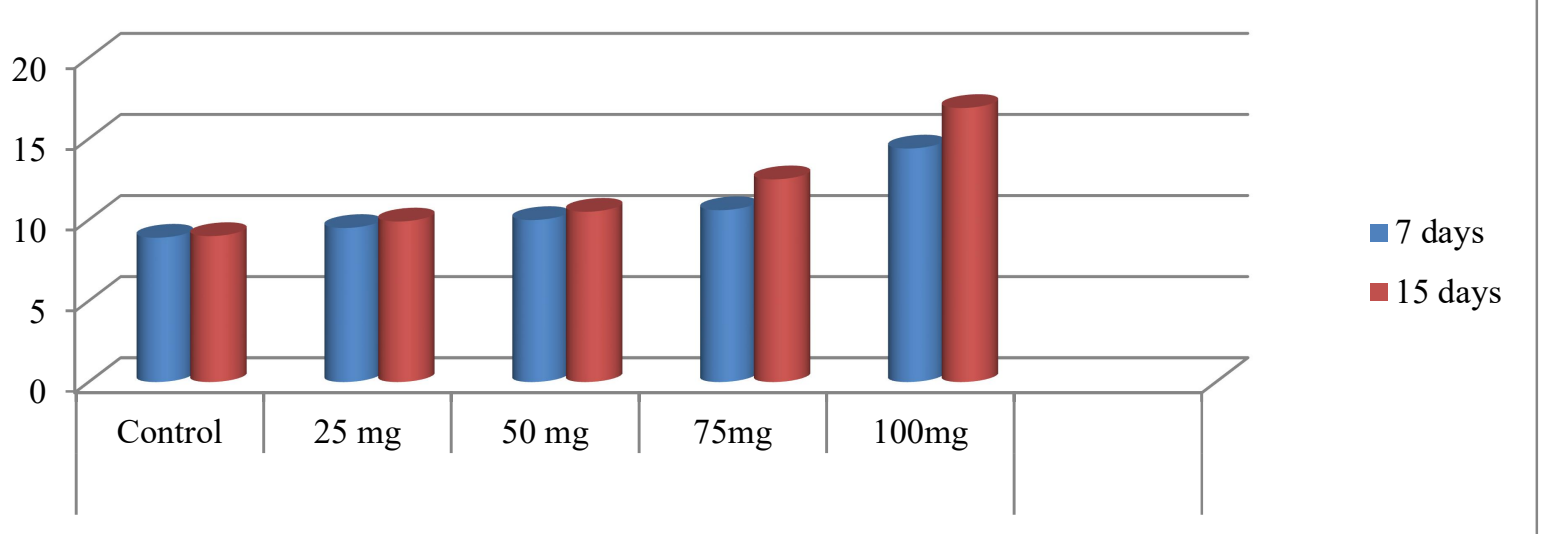

Fig 4. Effect of different dose of Malathion on WBCs cubic/mm

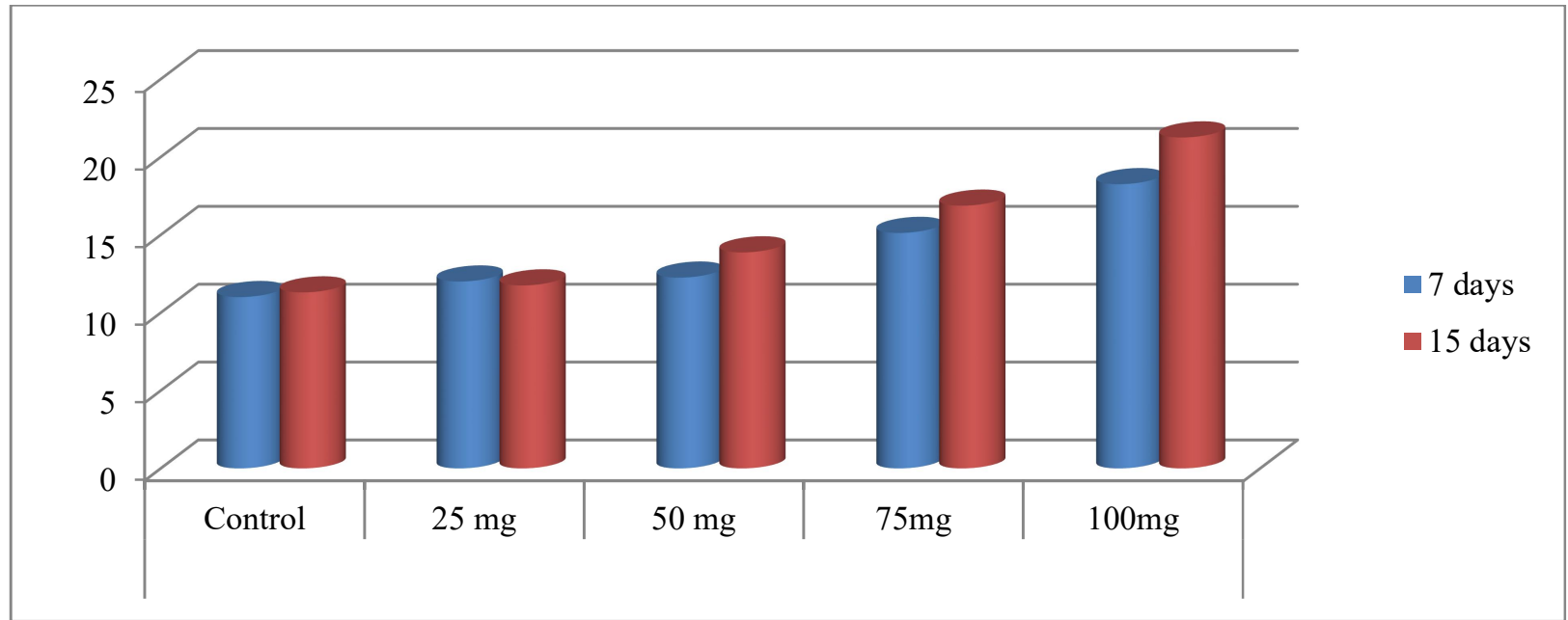

Fig 5. Effect of different dose of Malathion on ESR mm/hr

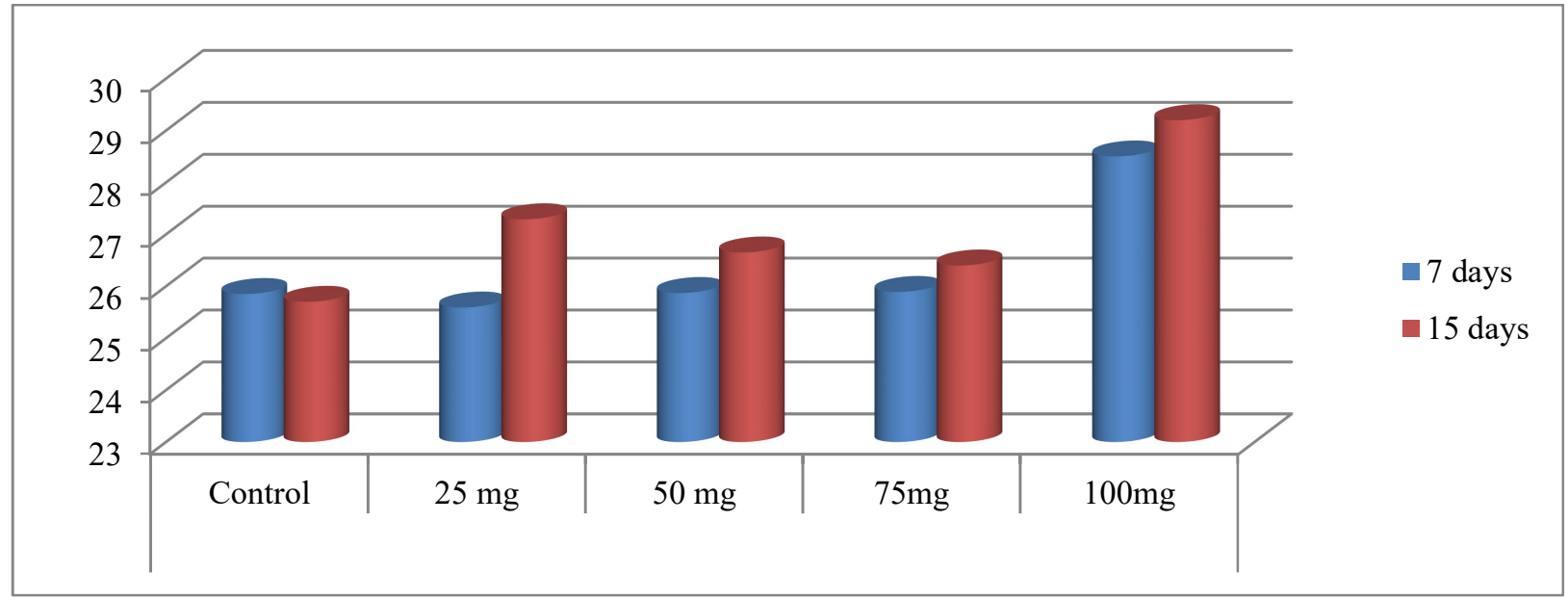

Fig 6. Effect of different dose of Malathion on MCV (fl) 


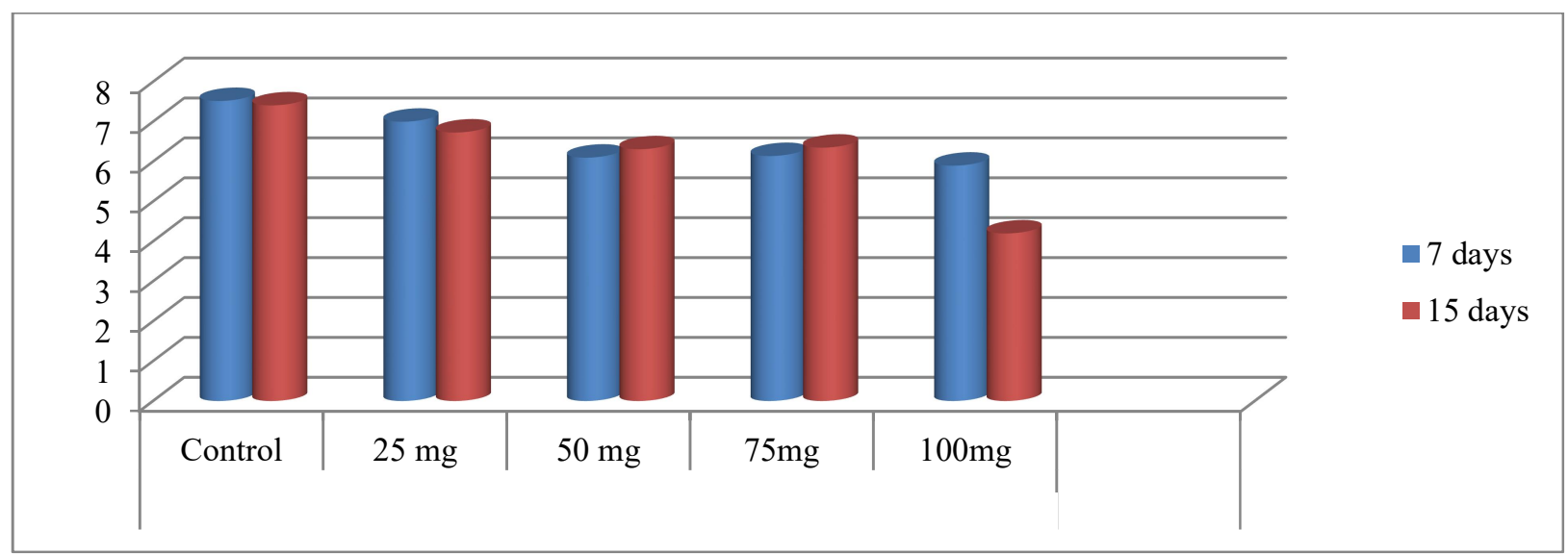

Fig 7. Effect of different dose of Malathion on MCH value (pg)

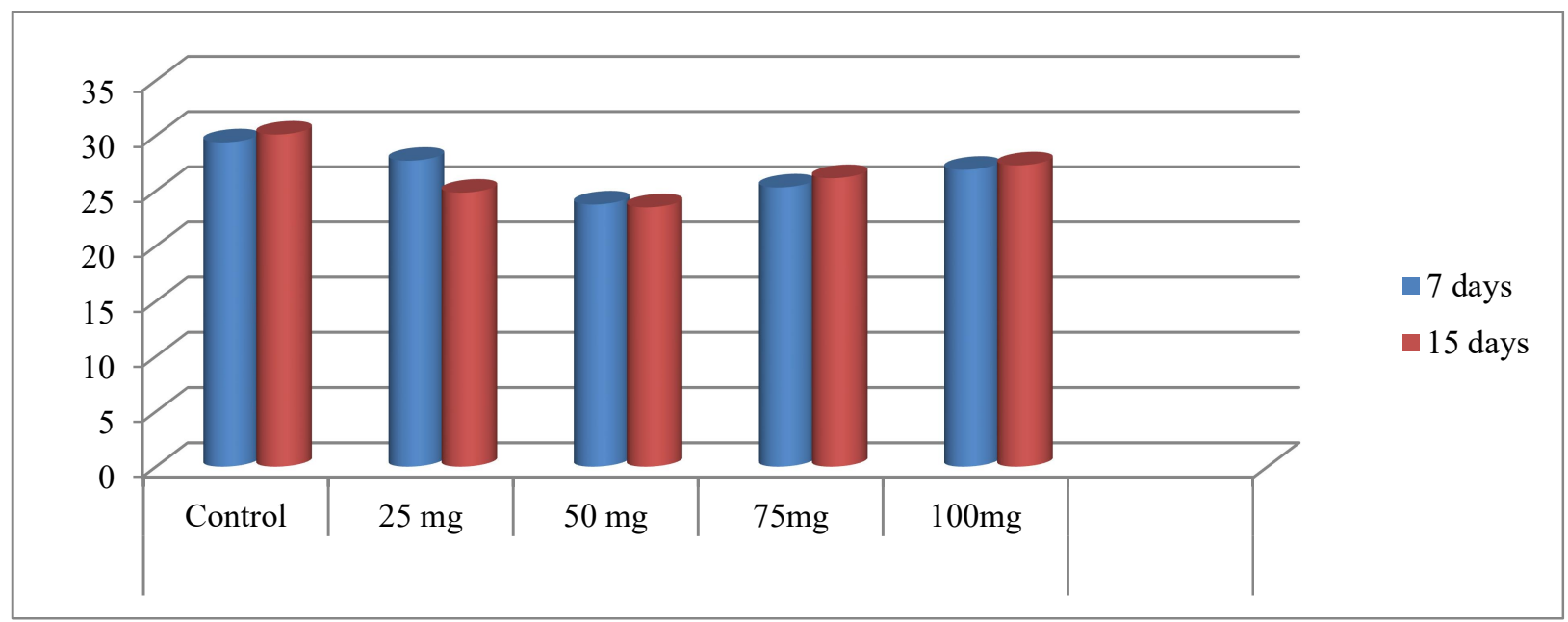

Fig 8. Effect of different dose of Malathion on MCHC (g/dl)

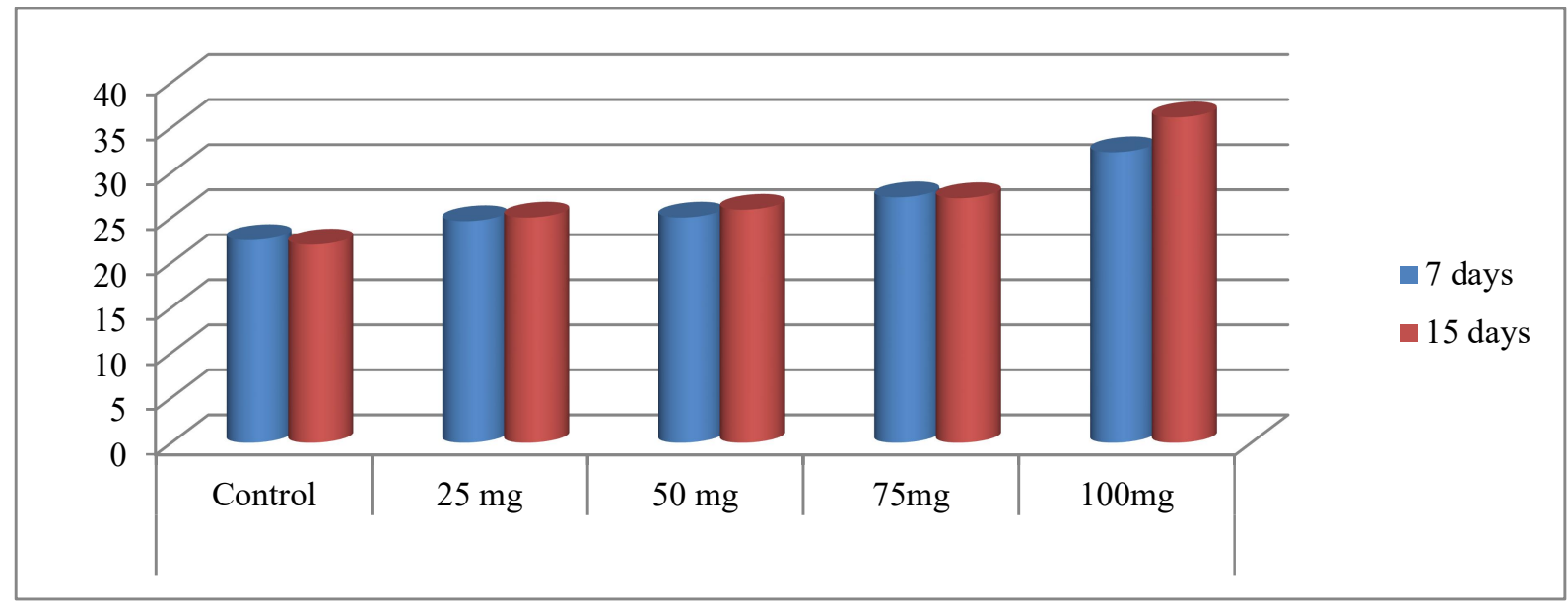

Fig 9. Effect of different dose of Malathion on P.T. /sec 


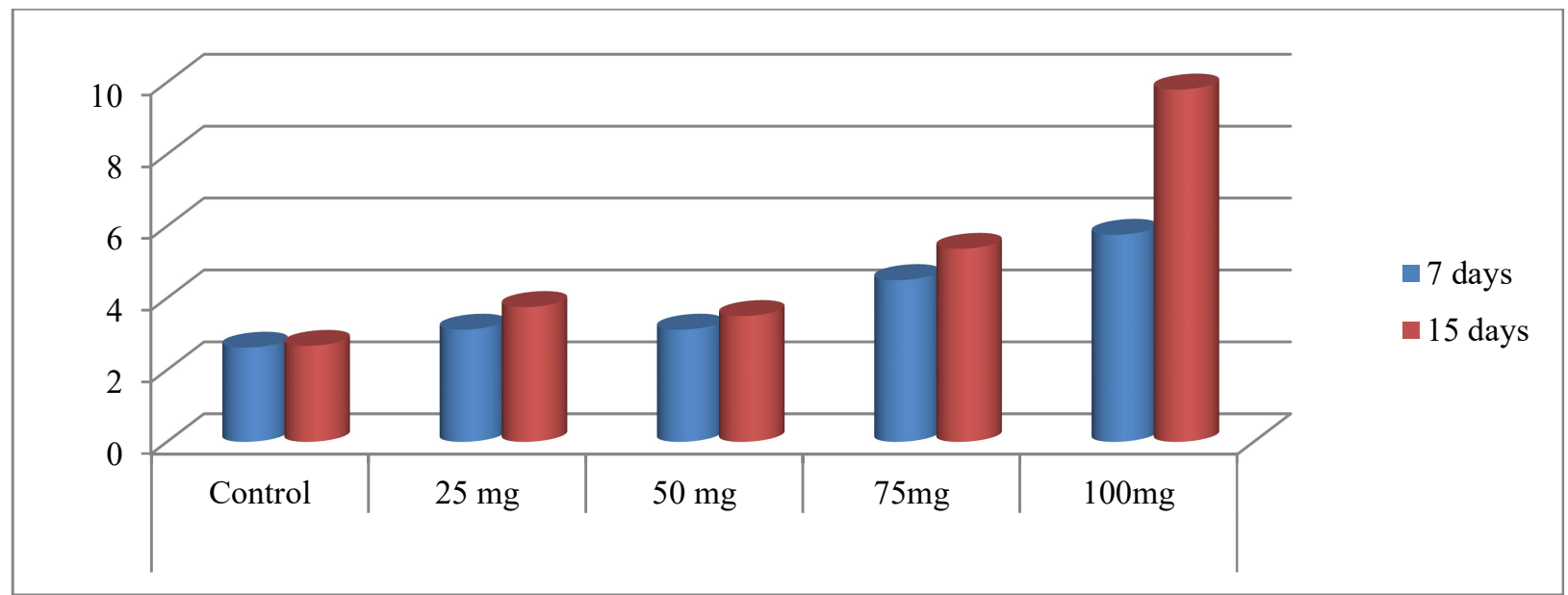

Fig 10. Effect of different dose of Malathion on C.T (min)

Bharti (1994) also reported toxicity of insecticide and behaviour of the blood clam of Anadora granosa.

\section{ESR and MCV}

Erythrocyte sedimentation rate and Mean corpuscular volume observations are given in table 1.The concentration of the erythrocytes in the blood was found increased during study period. The ESR represents (Fig. 5) a non-specific response to tissue damage and denotes the presence of disease, nephritis, acute hepatitis etc. When a dose of $25 \mathrm{mg}$ per kg body weight per day of Malathion following variations in the ESR observed insignificant an increase after 7 days of treatment was found as $9.09 \%$ while after 15 days an increament of $6.8 \%$ was observed. But with a dose of $50 \mathrm{mg}$ per kg body weight per day ESR was found increased after 7 days by $11.36 \%$ and after 15 days of treatment the ESR increased by $26.09 \%$.With the dose of $75 \mathrm{mg}$ per $\mathrm{kg}$ body weight per day and $100 \mathrm{mg}$ per $\mathrm{kg}$ body weight per day dose of malathion at 7 days the ESR increased by $37.45 \%$ while after 15 days it increases by $53.36 \%$.

\section{MCV (Mean Corpuscular Volume)}

With dose of $25 \mathrm{mg}$ per $\mathrm{kg}$ body weight per day of Malathion an increase after 7 days by $1 \%$ and 15 days of treatment by $5.57 \%$ was observed with a dose of $50 \mathrm{mg}$ per $\mathrm{kg}$ body weight per day MCV increases after 7 days by $0.07 \%$ and after 15 days it was observed as $3 \%$ while with a dose of $75 \mathrm{mg} / \mathrm{kg}$ body weight/day and 100mg per kg body weight per day of Malathion it was observed as $2.9 \%$ and after 15 days of treatment the MCV increases to $6.8 \%$ as shown in fig 6 .

\section{MCH (Mean corpuscular Hemoglobin)}

$\mathrm{MCH}$ observed is indicated in fig 7 the amount of haemoglobin in the red blood cells was found correlated with the MCV and MCHC.The value present in table 1 was calculated by the formula and found that the dose of Malathion causes variations in the $\mathrm{MCH}$. $\mathrm{MCH}$ decreased after 7 days of treatment by $6.9 \%$ and after 15 days of treatment the $\mathrm{MCH}$ decreased by $10.5 \%$. Findings were in agreement with those of the observations of Kumar et al. (2001) who reported that dimecron cause the changes of haematological parameter in fish Heteropneustes fossilis.

\section{MCHC (Mean Corpuscular Hemoglobin}

\section{Concentration)}

Result of different doses of MCHC are indicated in fig 8. MCHC was found decreased after 7 days of treatment by $5.61 \%$. while after 15 days it decreases by $15.45 \%$. With a dose of $50 \mathrm{mg} / \mathrm{kg}$ body weight/day decrease was observed as $19.10 \%$ after 7 day and after 15 days of treatment decreased was found as $19.78 \%$. With the dose of $75 \mathrm{mg}$ per $\mathrm{kg}$ body weight per day and 100mg per kg body weight per day $\mathrm{MCHC}$ decreased by $17.90 \%$ after 7 days and $10.90 \%$ after 15 days these results were found similar to those of Mehreen and Yousafzai (2017) who reported the negative effects of insecticides on rabbit. The Malathion pesticide increases the number of WBCs and RBCs, MCHC but some parameter were found decrease as $\mathrm{Hb}$, $\mathrm{MCV}$, and $\mathrm{MCH}$ etc. Atamanalp et al. (2002) concludes that the value of MCHC and other parameter of haematology of rainbow trout exposed to cypermethrin. Parma et al. (2007) reported the 
findings of the effect of cypermethrin similar to our findings in Prochilodus lineatus.

\section{PT (Prothrombin time)}

A Prothrombin time (Fig 9) is determined time in which fibrinogen, Prothrombin was made. When a dose of $25 \mathrm{mg}$ per $\mathrm{kg}$ body weight per day of Malathion following variations in the PT was observed an increase in 7 days of treatment was found as $11.1 \%$. While after 15 days of treatment PT increases by $8.3 \%$. With a dose of $50 \mathrm{mg}$ per $\mathrm{kg}$ body weight per day PT was found increased after seven days of treatment by $11 \%$ after 15 days of treatment increased was found as $14.97 \%$. With $75 \mathrm{mg}$ per $\mathrm{kg}$ body weight per day dose of Malathion for 7 and 15 days PT increase by $21.1 \%$ after 7 days of treatment and $23.3 \%$ respectively. When a dose of $100 \mathrm{mg}$ per $\mathrm{kg}$ body weight per day animals was administered the PT increase by $43.3 \%$ after 7 days of treatment and increase was highly significant as shown in (fig 5) after the treatment of 15 days the increase was observed $60.5 \%$. Hymavathi and Rao (2000) reported that lead also cause haematological changes in Channapunctatus.

\section{CT (Clotting Time)}

The clotting time is the time clinched between haemorahage to clot the formation. When $25 \mathrm{mg}$ per $\mathrm{kg}$ body weight per day of Malathion following variations in the $\mathrm{CT}(\mathrm{Fig}-\mathrm{X})$ were observed an increase in CT was found as $19 \%$ after 7 days of treatment and after 15 days of treatment the increase was observed as $43.13 \%$. With a dose of $50 \mathrm{mg}$ per $\mathrm{kg}$ body weight per day following variation CT increased by $1.9 \%$ after Seven days of treatment and after 15 days of treatment the increase was found as $33.5 \%$ with a dose of $75 \mathrm{mg}$ per kg body weight per day for 7 and 15 days CT was found increased by $7.1 \%$ and $10.4 \%$ respectively. When animals were orally administered with a dose of $100 \mathrm{mg}$ per $\mathrm{kg}$ body weight per day the CT (clotting time) increased after 7 days of treatment by $11.9 \%$ while an increase after 15 days of treatment was found as $31.9 \%$. The above findings are in agreement to those of Kori-Siakpere and Oboh (2011). Mehra et al. (2014) also reported similar findings. Reena et al. (1989) find the similar changes in Rat. Zaratzizian et al. (1961) injected Malathion $\mathrm{i} / \mathrm{p}$ in rats@ $500 \mathrm{mg} / \mathrm{kg}$. After 2 hours there was 70.53 and $60 \%$ inhibition of brain RBC and plasma ChE respectively. After 125 hours of treatment the inhibition was found 7.14 and $11 \%$. Distribution and excretion study in cattle were carried out by oral administration of p32 labelled Malathion by O'Brain (1967) who observed that $90 \%$ of the drug was excreted in the urine and rest through the faeces. They further observed that $69 \%$ of the dose was excreted in 4 days after the first dose and 23\% in the next 2 to 3 days. Bigoniyaa et al. (2015) find that the exposure of artesunate in rat changes the biochemical and hematological parameter. Garg et al. (1989) reported induced haematological and biochemical abnormalities in Heteropneustes fossilis by Manganese. Pickering et al. (1962) observed deleterious effects at the cellular level in the fish caused by intoxication of Malathion. Similarly Pasarela et al. (1962) observed that with $800 \mathrm{ppm}$ of Malathion for 41 to 44 days of experiment in cows no Malathion was found in blood, kidney, heart, muscles and fat. Isaac et al. (2013) reported the blood parameter of different breed of rabbit. Magar and Dube (2012) reported that the blood parameter of fish Channa punctatus effected by Malathion pesticide. Nagarjuna, (2007) find the similar findings in albino rats. Pimpao et al. (2007) previously find the effects of deltamethrin on hematological parameters and biochemical parameter.

\section{Conclusion}

The animals administered with different doses of Malathion, gradually lost their activity and became lethargic. In all the cases $\mathrm{Hb} \%$ and RBCs were lowered, also macrocytic anemia was visible as there was an increase in MCV. Erythrocytes in rodent blood were very much enlarged macrocytic anemia, the liver and RBCs are the main storage sites of foliate. It plays an important role in cellular metabolism by acting as co-enzyme for important biochemical reactions. Our findings on WBCs number, PT and CT time increase which indicate the toxic effects of Malathion pesticide.Because this pesticide is generally used in farming practice hence we suggest that the use of pesticide needs very carefull handling with proper precaution. Higher intake of protein diet may further reduce the hazards of pesticides.

\section{Acknowledgement}

Authors extend their sincere thanks to The Principal, D.N. (PG) College Meerut for providing 
Physiology and Biochemistry lab of Zoology Department. He provided facility and research atmosphere during Research. They are highly grateful to management and Principal KCSIT Bijnor as they helped the research with their valuable cooperation.

\section{References}

Akinrotimi, O.A., Abu, O.M.G., Ansa, E.J., Edun, O.M., George, O.S. 2009. Hematological responses of Tilapia guineensis to acute stress. Int J Nat Appl Sci., 5: 338-348.

Ambali, S.F., Abubakar, A.T., Shittu, M., Yaqub, L.S., Anafi, S.B., Abdullahi, A. 2010. Chlorpyrifos-induced alterations of hematological parameters in Wistar rats: Ameliorative effect of zinc. Res J Environ Toxicol., 4: 55-66.

Atamanalp, Y.T., Haliloglu, H. and Aras, M.S. 2002. Alterations in the hematological parameters of rainbow trout, Oncorhynchus mykiss, exposed to cypermethrin. The Israeli J Aquacult Bamidgeh, 54: 99-103.

Bhai, S., Idress, T. and Nath, N. 1971. Haematological changes in rats injected with aceto ace tate. Proc. Soc. Exp. Biol. Med., 138(2): 597-9.

Bharti, C. 1994. Toxicity of Insecticides and effects on the behaviour of the blood clam Anadoragranosa. Water, Air soil Poll., 75 (1\&2): 88-91.

Bigoniyaa, P., Sahua, T. and Tiwari, V. 2015. Hematological and biochemical effects of sub-chronic artesunate exposure in rats. Toxicol Rep., 2: 280-288.

Choudhary, N. and Joshi, S.C. 2002. Effect of short term endosulfan on hematology and serum analysis of male rat. Indian Journal of Toxicology, 9(2): 83-87.

Damalas, C.A. and Koutroubas, S.D. 2016. Farmers' Exposure to Pesticides: Toxicity Types and Ways of Prevention Toxics; 4:1-10.

Das, B.K and Mukherjee, S.C. 2003. Toxicity of cypermethrin in Labeo rohita fingerlings: biochemical, enzymatic and hematological consequences. Comp Biochem Physiol. Part C, 134: 109-121.

Garg, V.K., Garg, S.K. and Tyagi, S.K. 1989. Manganese induced haematological and biochemical abnormalities in Heteropneustes fossilis. J Environ Biol., 10: 349-353.

Hayes, W.J. and Laws, E.R. (ed.) 1990. Handbook of Pesticide Toxicology, Vol.3, Classes of Pesticides. Academic Press, Inc. NY.

Hymavathi, V. and Rao, L.M. 2000. Effect of Sublethal concentrations of lead on the haematology and biochemical

rats. Ph.D. Thesis, Sri Venkateswara University Tirupati, India. constituents of Channapunctatus. Bulletin of Pure and Applied Sciences, 19A(1): 1-5.

Isaac, L.J., Abah, G., Akpan, B. and Ekaette, I.U. 2013. Haematological properties of different breeds and sexes of rabbits. Proceedings of the 18th Annual Conference of Animal Science Association of Nigeria, p-24.

Jung- Hoon, J., Masroor, F. and Ju-Chan, K. 2005. Responses of cypermethrin - induced stress in haematological parameters of Korean rockfish, Sebastes schlegeli (Hilgendorf). Aquaculture Research, 36: 898-905.

Kartheek, R.M. and David, M. 2017. Modulations in Haematological Aspects of Wistar Rats Exposed to Sublethal Doses of Fipronil under Subchronic Duration. J. Pharmaceutical, Chemical and Biological Sciences, 5(3):187-194.

Kori-Siakpere, O. and Oboh, E.C. 2011. Haematological effects of sublethal concentrations of tobacco leaf dust on the African catfish: Clarias gariepinus (Burchell 1822). Arch Appl Sci Res; 3: 93-502.

Kumar, A.A, Tripathy, A.P. and Tripathy, A.K. 2001. Effect of dimecron on the blood parameter of Heteropneustes fossilis. J Environ Biol., 22: 297-299.

Kumar, A., D.M.H.S., John, N., Sushma, D.J., Kumar, S. and JayanthaRao, K. 1996. Haematological changes in albino rats under aldrin intoxication. Indian Journal of Comparative Animal Physiology, 14(1): 63-66.

Kumar, B. 1990. Histological and Histopathological changes induced by pesticides on the fresh water Teleost fish clarious balarchus, Ph. D. Thesis Patna University, Patna, India.

Madhavee, L.P. 2006. Effect of monocrotophos on selected biochemical parameters, light and electron microscope study on albino mice. Ph.D. Thesis, Sri Venkateswara University, Tirupati, India.

Magar, R.S. and Dube, K.V. 2012. Impact of malathion on some haematological parameters of Channa punctatus (Bloch). Int J Biomed Adv Res., 03: 683-685.

Mehra, B.L., Sharma, P., Kaushik, U. and Joshi, S.C. 2014. Effect of Fytolan on Haematology and Serum Parameters of Male Albino Rats. Int J Pharma Res Health Sci., 2: 332-338.

Mehreen, R. and Yousafzai, A.M. 2017. Toxic effects of insecticides malathion and cypermethrin on hematological parameters in blood of male rabbits (Oryctolagus cuniculus) JEZS, 5(3): 154-158.

Nagarjuna, 2007. Effect of cypermethrin on hematological, protein metabolism and histological studies in albino

Naik, M.M., Reddy, J.S.M., Sugunakar Y.J., Udaykiran, K.V. and Sivasankar, R. 2018. Alterations of hematological 


\section{Selected blood parameters altered by different doses of pesticide Malathion}

parameters under chlorpyrifosintoxication in mice. 7 ; (1-d); 8935-8944.

O' Brien, R.D. 1967. Effect of induction by pentobarbital upon susceptibility of Mice to Insecticides. Bull. Environ. contamin Toxico J., 2: 163.

Parma, M.J., Loteste, A., Campane, M. and Baccheta, C. 2007. Changes in haematological parameters in Prochilodus lineatus exposed to sublethal concentration of cypermethrin. J Environ Biol., 28: 147-149.

Pasarela, N.R., Brown, R.G. and Shafter, C. B.1962. Feeding of Malathion to cattle residue analysis of milk and tissue. J. Agri, Food Chem., 10, 7.

Pickering, Q.H.C., Henderson, and Lemke, A.E. 1962. The toxicity of organophosphorus insecticides to different sps. of warm water fishes. Trans, Amer, Fish-Soc., 91: 175184.

Pimpao, C.T., Zampronio, A.R. and De Assis, H.C.S. 2007. Effects of deltamethrin on hematological parameters and enzymatic activity in Ancistrus multispinis (Pisces, Teleostei). Pest Biochem Physiol., 88: 122-127.

Prasad, O. and Rai, G. 1988. Haematological changes Induced by feeding a common non- nutritative sweetemer saceharin in Albino mice. J. Environ Biol., 9(1): 39-44.

Pravabati, D.S. and Tombi, S.H. 1988. Azo-carmine induced Haematological and Bio-chemical changes in Albino rat (Rattus Norvegicus). J Environ Biol., 9(1): 21 - 25.

Rahman, M.F. and Siddiqui, M.K.J. 2006. Hematological and clinical chemistry changes induced by subchronic dosing of a novel phosphorothionate (RPR-V) in wistar male and female rats. Drug and Chemical Toxicology, 29: 95-110.
Rahman, M.F., Siddiqui, M.K.J., Mahaboob, M. and Mustafa, M.J. 1990. Hematological and hepatotoxic effects of isoprocrab in chicken. Journal of Applied Toxicology, 10(3): 187-92.

Reena, K., Ajay, K. and Sharma, C.B. 1989. Haematological changes induced by dimethoate in rat. Arh.Hig. Rad. Tokzikol., 40(1): 23-1.

Sharma, R.K. and Saxena, Y. 1983. Haematological study of Indian desert gerbil, Meriones hurrianae (Jerdon) after brodifacoum poisoning. Indian Journal of Comparative Animal Physiology, 1(2): 23-28.

Siddiqui, M.A. 2004.Toxicological and Immunological studies of subacute exposure of cockerels to imidacloprid and quinalphos. M.V.Sc. Thesis, Gujarat Agricultural University, Anand, India.

Singh, Z., Kaur, J., Kaur, R. and Hundal, S.S. 2016. Toxic Effects of Organochlorine Pesticides: A Review. Amer J Bios., 4:11-18.

Solanke, A.K and Singh, V.H. 2000. Haematological changes in rat, Rattusrattus after repeated exposure to thiodan 35 EC. Environmental and Ecology, 18(2): 529- 31.

Taylor, J.D. and Richards, R.K. 1968. Wiegand; Totxicological studies with Sodium Cyclamate and Saccharin, Fd, Cosmet. Toxicol., 6: 313-327.

Yekeen, T.A., Okorie, T.G. and Bakare, A.A. 2007. Acute and chronic toxicity of the synthetic pyrethroid deltamethrin in mice. Asian Journal of Microbiology, Biotechnology and Environmental Sciences, 9(1):11-17.

Zaratiziam, V.C., Arnnault, L.T., Michel, T.C. and Fitzhigh, O.G. 1961. Effects of organophosphates delnor and Malathion in dog. Fed Proc. 20. 432. 